\section{A modified protocol for total RNA isolation from different oil palm (Elaeis guineensis) tissues using cetyltrimethylammonium bromide}

\author{
Rashad Qadri ${ }^{1,2}$, Amjad Iqbal ${ }^{1,3}$, Yi Wu ${ }^{1}$, \\ Jing Li ${ }^{1}$, Numrah Nisar ${ }^{4}$, Muhammad Azam ${ }^{2}$ and \\ Yaodong Yang ${ }^{1}$ * \\ ${ }^{1}$ Hainan Key Laboratory of Tropical Oil Crops Biology/Coconut \\ Research Institute, Chinese Academy of Tropical Agricultural Science, \\ Wenchang, Hainan 571339, China \\ ${ }^{2}$ Institute of Horticultural Sciences, University of Agriculture, \\ Faisalabad, Pakistan \\ ${ }^{3}$ Department of Agriculture, Abdul Wali Khan University Mardan, \\ Pakistan \\ ${ }^{4}$ Department of Environmental Sciences, Lahore College for \\ Women University Lahore, Lahore 54600, Pakistan
}

Extraction of high-quality RNA from oil palm tissues is challenging due to the presence of polysaccharides, polyphenols and other complexes that co-precipitate with RNA. Therefore, isolation of high-quality RNA from oil palm is challenging due to the presence of varying amounts of these constituents in diverse tissues. This communication describes a modified RNA extraction protocol based on the cetyltrimethylammonium bromide (CTAB) method which is useful for extracting high-quality RNA from different oil palm tissues. Total RNA isolation using a modified CTAB protocol was compared with two different methods, a conventional TRIzol method and the method for RNA isolation from palms (MRIP). Both methods were useful for isolating RNA from leaf tissues; however, they were not effective in isolating RNA from other tissues. The current protocol based on a modified CTAB method was efficient in isolating high-quality total RNA from oil palm fruit tissues, including mesocarp and endosperm, stem, root and flower tissues. This modified CTAB-based protocol gave approximately 20 $30 \mu \mathrm{g}$ of total RNA from $150 \mathrm{mg}$ of tissue within 5-6 h.

Keywords: CTAB method, gene expression, oil palm, RNA extraction.

OIL palm (Elaeis guineensis) is one of the leading sources of edible oil today ${ }^{1}$; it yields tenfold higher oil than soybean $^{2}$. Palm oil is extracted from the fruit pulp (mesocarp) and palm kernel (endosperm) of oil palm. Though 1 ha of oil palm produces about 10-35 tonnes of fresh fruit bunches per year ${ }^{3}$, there is a huge gap between production and demand of palm oil. It is crucial to improve the quality and yield of palm oil to meet the needs of an increasing population ${ }^{4}$. Worldwide increase in the demand of vegetable oil necessitates an insight into the molecular

\footnotetext{
*For correspondence. (e-mail: yyang@catas.cn)
}

mechanism that regulates oil synthesis and fatty acid composition in oil palm fruit. WRINKLED1 (WRI1), a transcription factor (TF) and a key player in seed maturation can regulate glycolysis and fatty acid (FA) biosynthesis in higher plants ${ }^{5,6}$. However, to study the expression profile of WRII genes in different tissues and to verify the role of regulatory factors and/or target genes in oil palm fatty acid synthesis, extraction of high-quality RNA is required.

The first step in molecular biology experiments (e.g. isolation of the gene of interest by PCR-based technologies, establishment of cDNA libraries and expression studies) is extraction of high-quality RNA. Presence of high level of polyphenols and polysaccharides in most plant materials greatly affects the isolation of high-quality RNA in appreciable quantities ${ }^{7,8}$. Several RNA extraction methods have been developed over the years to isolate high-quality RNA from diverse species ${ }^{9-13}$. Besides, multiple commercial kit reagents for RNA isolation from plant tissues are also available, including RNeasy plant kit (QIAGEN, China) and TRIzol (Invitrogen, China). However, these kits are not always effective for the isolation of quality RNA from complex plant tissues (mainly oil palm) due to the presence of high amounts of polyphenols, polysaccharides, and other secondary metabolites ${ }^{14-16}$. To solve this problem, a modified CTAB method has been developed to extract high quality and quantity of RNA from a wide range of oil palm tissues. The proposed method will help the palm molecular biologists isolate quality RNA from complex palm tissues and utilize it in downstream experiments.

The reagents used in the assay were composed of 0.5 M EDTA stock, $5 \mathrm{M} \mathrm{NaOH}$ solution, $1 \mathrm{M}$ Tris $\mathrm{HCl}$ stock ( $\mathrm{pH} 8.0$ ), $5 \mathrm{M} \mathrm{NaCl}$ and $3 \mathrm{M} \mathrm{NaAc}(\mathrm{pH}$ 5.2). The extraction buffer was composed of $20 \mathrm{ml} 1 \mathrm{M}$ Tris $-\mathrm{HCl}$ (pH 8.0), $120 \mathrm{ml} 5 \mathrm{M} \mathrm{NaCl}$ and $10 \mathrm{ml} 0.5 \mathrm{M}$ EDTA, $4 \mathrm{~g}$ CTAB and $4 \mathrm{~g}$ PVP in $100 \mathrm{ml}$ of water. The final volume of the mixture was adjusted to $250 \mathrm{ml}$ with $\mathrm{H}_{2} \mathrm{O}$. $\beta$ mercaptoethanol $(\beta \mathrm{ME})(2 \%)$ was added to the extraction buffer before use to reduce the possibility of oxidation.

The steps in the extraction of RNA from oil palm tissues consisted of tissue collection and grinding (1-2 h for 10 samples), extraction of RNA from the ground tissue (approximately 2-3 h), RNA precipitation and washing (approximately 1.5-2 h), measuring RNA concentration (15 min for 10 samples) and checking RNA quality by electrophoresis $(1.5 \mathrm{~h})$. To isolate high-quality RNA the following steps were carried:

1. The frozen tissue was collected from $-80^{\circ} \mathrm{C}$ freezer in liquid nitrogen to avoid thawing until proceeding to the next step. (In high-quality RNA isolation tissue collection is important. Plant tissues should be frozen in liquid nitrogen immediately after collection and maintained at $-80^{\circ} \mathrm{C}$ prior to step 2.) 
2. Mortar and pestle were pre-cooled by pouring liquid nitrogen on them. The frozen tissues were placed in the mortar containing liquid nitrogen and ground with a pestle to get the fine powder. Next, the powdered frozen sample was carefully transferred into a $2 \mathrm{ml}$ polypropylene tube with the help of pre-cooled spatula (pre-cooled in liquid nitrogen). (Do not let the tissue thaw during grinding. If necessary, add more liquid nitrogen slowly and continue until the sample becomes a fine powder. Secondly, evaporate all the liquid nitrogen before sealing the tube. Sealed tube with liquid nitrogen may pop open, resulting in loss of sample).

3. The powdered microfuge tubes were immediately placed in liquid nitrogen.

4. The sample was maintained at $-80^{\circ} \mathrm{C}$ until proceeding to step 5.

5. Extraction buffer was pre-heated to $65^{\circ} \mathrm{C}$ in a water bath.

6. Next, $1 \mathrm{ml}$ of preheated extraction buffer was added to $150 \mathrm{mg}$ of powdered tissue, followed by vigorous shaking/vortexing for $15-20 \mathrm{sec}$ at room temperature (RT).

7. Equal volume of chloroform : isoamyl alcohol (24: 1 $\mathrm{v} / \mathrm{v}$ ) was added to the mixture and vortexed for 5 min.

8. The mixture was centrifuged at $13,000 \mathrm{~g}$ for $10 \mathrm{~min}$ at $4{ }^{\circ} \mathrm{C}$.

9. The supernatant (not $>700-800 \mu \mathrm{l}$ ) was transferred into a new $2 \mathrm{ml}$ microfuge tube.

10. Next, $500 \mu \mathrm{l}$ chloroform : isoamyl alcohol (24:1 $\mathrm{v} / \mathrm{v})$ was added to the supernatant and vortexed for 15-20 sec at RT.

11. The mixture was centrifuged at $13,000 \mathrm{~g}$ for $10 \mathrm{~min}$ at $4{ }^{\circ} \mathrm{C}$.

12. The supernatant was transferred (not $>600-700 \mu \mathrm{l}$ ) into a new $2 \mathrm{ml}$ microfuge tube.

13. Next $500 \mu \mathrm{l}$ of phenol : chloroform : isoamyl alcohol $(25: 24: 1 \mathrm{v} / \mathrm{v})$ was added to the supernatant and vortexed for 5-10 sec at RT.

14. The phases were separated by centrifuging the mixture at $13,000 \mathrm{~g}$ for $10 \mathrm{~min}$.

15. The upper aqueous phase (not $>500-600 \mu \mathrm{l}$ ) was carefully transferred to a new $2 \mathrm{ml}$ microfuge tube.

16. Next, $500 \mu \mathrm{l}$ of chloroform : isoamyl alcohol (24:1 $\mathrm{v} / \mathrm{v}$ ) was added to the supernatant of the previous step to remove traces of phenol.

17. The tube was gently vortexed and centrifuged at $13,000 \mathrm{~g}$ for $10 \mathrm{~min}$ at $4^{\circ} \mathrm{C}$.

18. The supernatant (not $>400 \mu \mathrm{l}$ ) was transferred to a new $1.5 \mathrm{ml}$ microfuge tube.

19. Next three volumes of cold absolute $\mathrm{EtOH}\left(4^{\circ} \mathrm{C}\right)$ and 0.1 volume of $3 \mathrm{M}$ sodium acetate $(\mathrm{pH} 5.2)$ were added to the recovered aqueous phase and nucleic acid was precipitated.
20. After gently mixing by inverting the tube, the sample was stored till frozen or stored overnight at $-80^{\circ} \mathrm{C}$.

21. Frozen tubes were centrifuged at $13,000 \mathrm{~g}$ for $20 \mathrm{~min}$ at $4^{\circ} \mathrm{C}$.

22. The supernatant was discarded and $1 \mathrm{ml}$ of $75 \%$ EtOH was added to wash out the pellet and centrifuged as described in step 21 .

23. The supernatant was carefully removed without disturbing the pellet. The pellet was air-dried for $10 \mathrm{~min}$ to remove residual alcohol.

24. The pellet was then dissolved in $40-50 \mu \mathrm{l}$ of RNase free water.

RNA concentration was determined spectrophotometrically by taking absorbance readings at 230, 260 and $280 \mathrm{~nm}$ to determine the presence of organic impurities (polysaccharides and polyphenolics).

The quality of RNA was determined by agarose gel electrophoresis.

(i) Total RNA was electrophoresed in $1.2 \%$ (wt/vol) agarose gel.

(ii) The mixture was heated until agarose completely dissolved in the buffer; it was then cooled to $50^{\circ} \mathrm{C}$. Next ethidium bromide $\left(0.5 \mu \mathrm{g} \mathrm{ml}^{-1}\right)$ was added and the gel poured into a gel mould held in a cassette with the comb. The gel was allowed to harden for about $20 \mathrm{~min}$. Then approximately $5 \mu \mathrm{g}$ of total RNA mixed with $2 \mu \mathrm{l}$ of $6 \times$ loading buffer was loaded into each well.

(iii) The gel mould was transferred into a container with $0.5 \times$ TBE buffer and the tank was connected to the power supply. The gel was electrophoresed at $120 \mathrm{~V}$ for $20 \mathrm{~min}$ and finally RNA bands were visualized using gel imaging system.

To utilize total RNA in downstream applications, $3 \mu \mathrm{g}$ of total RNA from each oil palm sample was reverse transcribed with the TaKaRa PrimeScript II 1st strand cDNA synthesis kit and oligo dT according to the manufacturer's instruction. Semi-quantitative RT-PCR was performed to check the quality of cDNA using TaKaRA PrimeScript II 1st strand cDNA synthesis kit as follows: $10 \mu \mathrm{l} 5 \times$ buffer Taq buffer, $1 \mu \mathrm{l}$ of both sense and antisense gene-specific primers $(10 \mu \mathrm{M}$ each $), 1 \mu \mathrm{dNTP}$ $\operatorname{mix}(10 \mathrm{mM}), 0.1 \mu \mathrm{l} \mathrm{Taq}$ polymerase $(5 \mathrm{U} / \mu \mathrm{l}$; Real Taq) and $36.4 \mu \mathrm{l} \mathrm{H}_{2} \mathrm{O}$. PCR amplifications were performed with an TaKaRa thermocycler, using the following conditions: $3 \mathrm{~min}$ at $94^{\circ} \mathrm{C}$ (denaturation); 25-32 cycles with each cycle for $30 \mathrm{sec}$ at $94^{\circ} \mathrm{C} ; 30 \mathrm{sec}$ at $55^{\circ} \mathrm{C} ; 30 \mathrm{sec}$ at $72^{\circ} \mathrm{C}$ (annealing); $10 \mathrm{~min}$ at $72^{\circ} \mathrm{C}$ (extending). For WRI 1 amplification primers were designed according to sequence information of the Elaeis guineensis cDNA libraries from the literature ${ }^{17,18}$. PCR amplification for WRI1 was performed using the following primers: forward: 5'-ATGACTCTCATGAAGAACTCT-3' and 
RESEARCH COMMUNICATIONS

Table 1. Yield and purity of RNA isolated from different oil palm tissues

\begin{tabular}{lccc}
\hline \multirow{2}{*}{ Oil palm tissue } & \multicolumn{2}{c}{ Absorbance ratio } & \\
\cline { 2 - 3 } & $260 / 280$ & $260 / 230$ & Concentration $(\mathrm{ng} / \mu \mathrm{l})$ \\
\hline Leaf & $1.95 \pm 0.02$ & $1.89 \pm 0.01$ & $730.6 \pm 100.45$ \\
Shoot & $1.89 \pm 0.05$ & $1.83 \pm 0.06$ & $671.1 \pm 128.0$ \\
Root & $1.96 \pm 0.03$ & $1.93 \pm 0.06$ & $676.4 \pm 84.6$ \\
Female flower unopend & $2.02 \pm 0.02$ & $2.02 \pm 0.02$ & $616.2 \pm 15.9$ \\
Female flower opend & $1.92 \pm 0.06$ & $1.94 \pm 0.06$ & $835.5 \pm 128.0$ \\
Male flower unopened & $1.84 \pm 0.06$ & $1.85 \pm 0.09$ & $1352.3 \pm 231.3$ \\
Male flower opened & $1.87 \pm 0.05$ & $1.84 \pm 0.06$ & $839.4 \pm 171.9$ \\
Mesocarp young & $1.96 \pm 0.03$ & $1.98 \pm 0.04$ & $579.9 \pm 42.2$ \\
Mesocarp mature & $1.86 \pm 0.06$ & $1.81 \pm 0.06$ & $529.1 \pm 54.7$ \\
Endospem mature & $1.98 \pm 0.06$ & $1.92 \pm 0.07$ & $1016.4 \pm 311.7$ \\
\hline
\end{tabular}

Values are means of three replicates with \pm indicates SD.

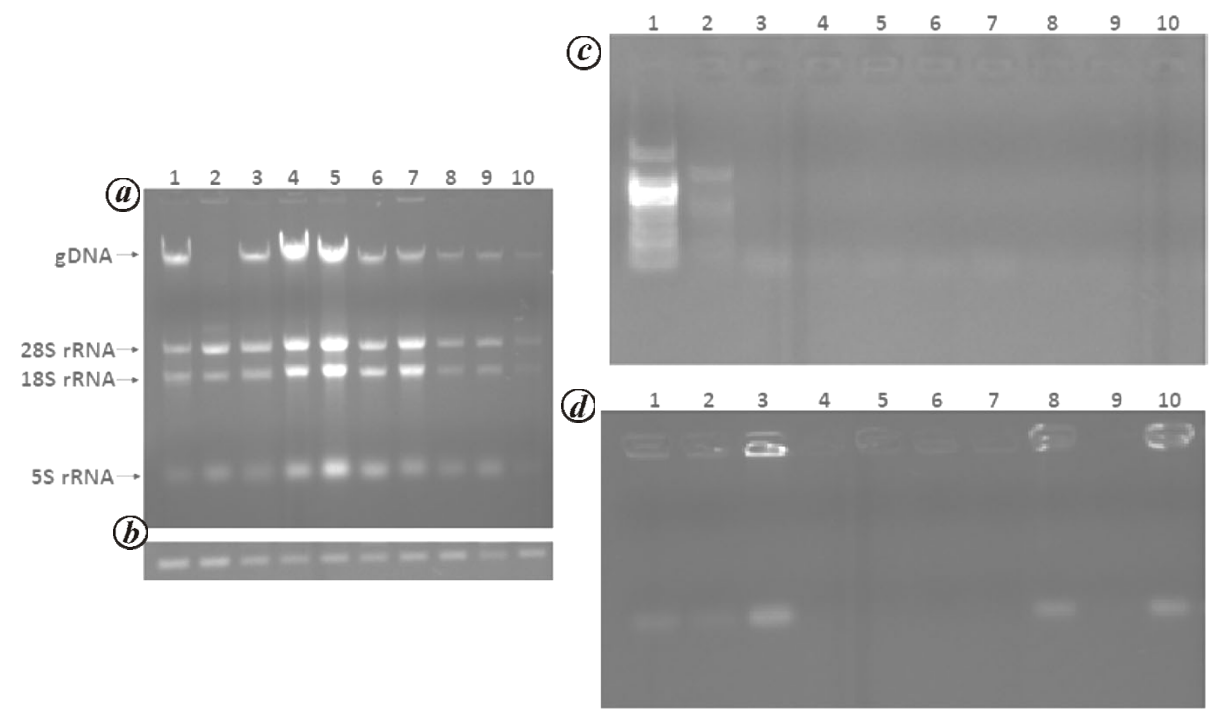

Figure 1. Isolation of RNA from various tissues of oil palm using different methods. (a) Total RNA (1 $\mu \mathrm{g})$ extracted at once from different oil palm organs by modified CTAB method; $(\boldsymbol{b})$ RT-PCR for beta-actin reference gene. $(\boldsymbol{c}, \boldsymbol{d})$ Total RNA $(1 \mu \mathrm{g})$ extracted at once from different oil palm organs using (c) MRIP buffer and $(\boldsymbol{d})$ TRIzol reagent. Numbers indicate different organs, i.e. (1) leaf, (2) stem, (3) root, (4) female unopened flower, (5) female opened flower, (6) male unopened flower, (7) male opened flower, (8) mesocarp young, (9) mesocarp mature and (10) endosperm mature.

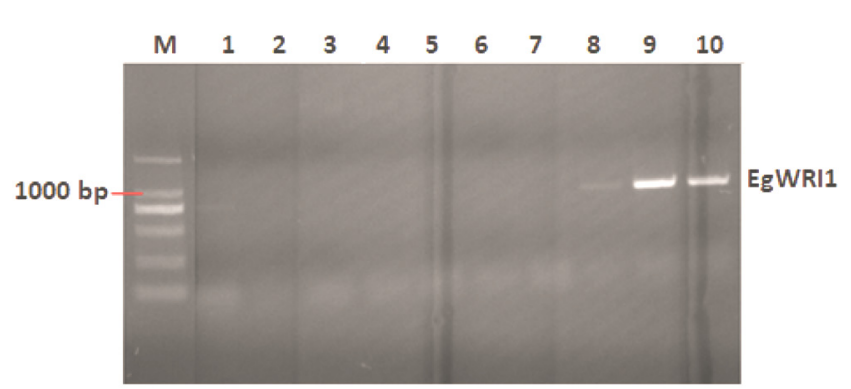

Figure 2. Agarose gel electrophoresis of RT-PCR analysis. RT-PCR amplification of EgWRI1 fragment with EgWRI1F1 and EgWRI1R1 primers using total RNA isolated by modified CTAB method from different oil palm organs: (1) leaf, (2) stem, (3) root, (4) female unopened flower, (5) female opened flower, (6) male unopened flower, (7) male opened flower, (8) mesocarp young, (9) mesocarp mature and (10) endosperm mature. M, DNA ladder. reverse: 5'-CTAGGCACCTTTGCTTGCA-3'. Beta-actin (forward: 5'-ATAAAGTATGGCTGATGCTGAGG-3 and reverse: 5'-CAACAATGCTTGGGAACACA-3) was used as reference gene. The designed primers were intronspanning to avoid amplification of genomic DNA.

The results showed that the modified CTAB RNA isolation method produced high-quality and quantity of RNA from different oil palm tissues, which may serve as a promising method of RNA isolation from palm. Even though MRIP performed well in case of palm leaves, it was inefficient in extracting quality RNA from other tissues of palm. The modified RNA isolation protocol discussed here compared well with other protocols such as MRIP ${ }^{19}$ and TRIzol (standard method), likely that best method to extract RNA from several tissues of oil palm 
(Figure 1). The quantity and purity of the isolated RNA were determined using a Nanodrop-2000 spectrophotometer. The absorbance ratios $A_{260 / 280}$ and $A_{260 / 230}$ of the isolated RNA (extracted using the modified CTAB method) ranged from 1.95 to 2.02 and 1.81 to 2.02 respectively (Table 1), suggesting that the resulting RNA was of high quality and purity ${ }^{20,21}$.

In order to examine the quality of extracted RNA, about $2 \mu \mathrm{g}$ of total RNA was separated on $1.2 \%$ agaroseethidium bromide gel (Figure 1). All RNA samples exhibited bands of $28 \mathrm{~S}$ rRNA and $18 \mathrm{~S}$ rRNA, indicating acceptable quality and purity of RNA (Figure $1 a$ ). Other methods (MRIP buffer and TRIzol) were unable to extract RNA from various reproductive tissues (Figure $1 c$ and $d$ ). Actin was used as control (Figure $1 b$ ). The resulting RNA was used in real-time RT-PCR assays to test if the quality was acceptable for downstream applications. We chose WRI1 as candidate to assess its expression in different tissues. Semi-quantitative RT-PCR was performed after extraction of RNA from various tissues. EgWRI1 transcripts were detected in mesocarp (young and mature), endosperm and leaf (Figure 2).

Multiple methods have been used to extract RNA from the oil palm tissues, but without any success. The method described here is relatively easy, cheap and capable of isolating RNA efficiently from various oil palm tissues, rich in polyphenols and polysaccharides.

1. Alain, R. and Larkins, B. A., Biotechnology in Agriculture and Forestry, Springer-Verlag, Heidelberg, Germany, 2007, vol. 63, pp. $59-80$.

2. Nair, P., Oil palm (Elaeis guineensis Jacquin). In The Agronomy and Economy of Important Tree Crops of the Developing World, Elsevier Inc., London, UK, 2010, pp. 209-236.

3. Singh, R. P., Hakimi Ibrahim, M. Norizan Esa and Iliyana, M. S., Composting of waste from palm oil mill: a sustainable waste management practice. Rev. Environ. Sci. Biotechnol., 2010, 9, 331344.

4. Sambanthamurthi, R., Singh, R., Kadir, A. P. G., Abdullah, M. O. and Kushairi, A., Opportunities for the oil palm via breeding and biotechnology. In Breeding Plantation Tree Crops: Tropical Species, Springer, 2009, pp. 377-421.

5. Baud, S., Mendoza, M. S., To, A., Harscoët, E., Lepiniec, L. and Dubreucq, B., WRINKLED1 specifies the regulatory action of leafy cotyledon 2 towards fatty acid metabolism during seed maturation in arabidopsis. Plant J., 2007, 50, 825-838.

6. Maeo, K. et al., An ap2-type transcription factor, wrinkled1, of arabidopsis thaliana binds to the aw-box sequence conserved among proximal upstream regions of genes involved in fatty acid synthesis. Plant J., 2009, 60, 476-487.

7. Helen, H. T., Pelletier, C. and Beardmore, T., Total RNA isolation from Picea mariana dry seed. Plant Mol. Biol. Rep., 2004, 22, 93a-93e.

8. Wang, X., Tian, W. and Li, Y., Development of an efficient protocol of rna isolation from recalcitrant tree tissues. Mol. Biotechnol., 2008, 38, 57-64.

9. Salzman, R. A., Fujita, T., Zhu-Salzman, K., Hasegawa, P. M. and Bressan, R. A., An improved RNA isolation method for plant tissues containing high levels of phenolic compounds or carbohydrates. Plant Mol. Biol. Rep., 1999, 17, 11-17.
10. Li, J.-H., Tang, C.-H., Song, C.-Y., Chen, M.-J., Feng, Z.-Y. and Pan, Y.-J., A simple, rapid and effective method for total RNA extraction from Lentinula edodes. Biotechnol. Lett., 2006, 28, 1193-1197.

11. Chun Jun, Z. Y.-F., Sheng-Hua, W. and Fang, C., A RNA isolation method suitable for a wide range of materials. Prog. Biochem. Biophys., 2008, 35, 591-597.

12. Thanh, T., Omar, H., Abdullah, M. P., Chi, V. T. Q., Noroozi, M., $\mathrm{Ky}, \mathrm{H}$. and Napis, S., Rapid and effective method of RNA isolation from green microalga Ankistrodesmus convolutus. Mol. Biotechnol., 2009, 43, 148-153.

13. Takahashi, H. et al., A method for obtaining high quality RNA from paraffin sections of plant tissues by laser microdissection. J. Plant Res., 2010, 123, 807-813.

14. Tattersall, E. A., Ergul, A., AlKayal, F., DeLuc, L., Cushman, J. C. and Cramer, G. R., Comparison of methods for isolating highquality RNA from leaves of grapevine. Am. J. Enol. Viticult., 2005, 56, 400-406.

15. Hou, P., Xie, Z., Zhang, L., Song, Z., Mi, J., He, Y. and Li, Y., Comparison of three different methods for total RNA extraction from Fritillaria unibracteata, a rare Chinese medicinal plant. $J$. Med. Plants Res., 2011, 5, 2835-2839.

16. Kiefer, E., Heller, W. and Ernst, D., A simple and efficient protocol for isolation of functional RNA from plant tissues rich in secondary metabolites. Plant Mol. Biol. Rep., 2000, 18, 33-39.

17. Bourgisa, F., Kilaruc, A., Caod, X., Ngando-Ebonguee, G.-F., Driraf, N., Ohlrogged, J. B. and Arondela, V., Comparative transcriptome and metabolite analysis of oil palm and date palm mesocarp that differ dramatically in carbon partitioning. Metabolism, 2011, 156, 564-584.

18. Tranbarger, T. J. et al., Regulatory mechanisms underlying oil palm fruit mesocarp maturation, ripening, and functional specialization in lipid and carotenoid metabolism. Plant Physiol., 2011, 156, 564-584

19. Xiao, Y. et al., Efficient isolation of high quality RNA from tropical palms for RNA-Seq analysis. Plant Omics, 2012, 5, 584.

20. Bernardo, G. D., Gaudio, S. D., Galderisi, U., Cascino, A. and Cipollaro, M., Comparative evaluation of different DNA extraction procedures from food samples. Biotechnol. Prog., 2007, 23, 297-301.

21. Wilfinger, W. W., Mackey, K. and Chomczynski, P., Effect of pH and ionic strength on the spectrophotometric assessment of nucleic acid purity. BioTechniques, 1997, 22, 474-481.

ACKNOWLEDGEMENTS. This work was supported by Key Laboratory of Plant Resources Conservation and Sustainable Utilization, South China Botanical Garden, Chinese Academy of Sciences funds (PCU201402) and 948 projects for Ministry of Agriculture of China (2015-Z25).

Received 22 February 2018; revised accepted 17 October 2018

doi: $10.18520 / \mathrm{cs} / \mathrm{v} 116 / \mathrm{i} 3 / 479-482$ 